Published in the Journal of Historical Sociology, 17(4), December 2004, pp. 428-63.

\title{
Social Darwinism in Anglophone Academic Journals: A Contribution to the History of the Term
}

\author{
GEOFFREY M. HODGSON
}

'Social Darwinism, as almost everyone knows, is a Bad Thing.'

Robert C. Bannister (1979, p. 3)

\begin{abstract}
This essay is a partial history of the term 'Social Darwinism'. Using large electronic databases, it is shown that the use of the term in leading Anglophone academic journals was rare up to the 1940s. Citations of the term were generally disapproving of the racist or imperialist ideologies with which it was associated. Neither Herbert Spencer nor William Graham Sumner were described as Social Darwinists in this early literature. Talcott Parsons (1932, 1934, 1937) extended the meaning of the term to describe any extensive use of ideas from biology in the social sciences. Subsequently, Richard Hofstadter (1944) gave the use of the term a huge boost, in the context of a global anti-fascist war.
\end{abstract}

\footnotetext{
$* * * * *$
} 
A massive 1934 fresco by Diego Rivera in Mexico City is entitled 'Man at the Crossroads'. To the colorful right of the picture are Diego's chosen symbols of liberation, including Karl Marx, Vladimir Illych Lenin, Leon Trotsky, several young female athletes and the massed proletariat. To the darker left of the mural are sinister battalions of marching gas-masked soldiers, the ancient statue of a fearsome god, and the seated figure of a bearded Charles Darwin. These conceptions of good and evil, progress and regress, and light and shade, were prominent in much of Western social science for the next fifty years. ${ }^{1}$

\section{Introduction}

Social Darwinism has been blamed for providing ideological and pseudo-scientific motivations for a number of twentieth-century horrors. These include eugenics, two world wars, Nazism and the Holocaust (Perry, 1918; Hofstadter, 1944; Crook, 1994; Hawkins, 1997). Probably the majority of social scientists would protest against racism, fascism, imperialism or sexism, and against any abuse of biology in support of these doctrines. I count myself as one of these protestors.

This essay differs from preceding accounts in that it is primarily a contribution to the history of the term itself, rather than of the impact of Darwinism on social science and political ideology. ${ }^{2}$ I ask: who used the term and what did they mean by it? I trace the uses of the term 'Social Darwinism' within the academic journals of the Anglo-American academic community, whose scientific literature became dominant over all others by $1945 .^{3}$

Although earlier histories (Hofstadter, 1944; Jones, 1980) also concentrate on the Anglophone community, they present as historical fact what has been and continues to be a pejorative, 
polemical label. To question this view does not in any way diminish the importance of attacking unfounded, reactionary or regressive ideas wherever they appear. Rather it will demonstrate that historical misrepresentation, and the use of 'Social Darwinism' as a term of abuse, have served not only partisan political ends, but have foreclosed discussion of the importance of ideas from biology in helping to understand human affairs.

Science does not stand separate from society or politics, but it has standards of openness, veracity and rigor. A worry is that the term 'Social Darwinism' has been used in the twentieth century to close down much of the discussion in the social sciences concerning the influence of human biology on human behavior. Typically with inaccurate accounts of its past usage, it has forced an unwarranted division between conceptualizations of the natural and the social. The acute effects of these closures and divisions still endure in modern anthropology and sociology. They are particularly damaging at the present juncture, because we are experiencing an explosion in the application of Darwinian and other evolutionary ideas in the human sciences. The important philosophical and conceptual implications of Darwinism for social science are now widely acknowledged. Those misguided by the rhetoric of 'Social Darwinism' are less well prepared to engage with these developments.

The result of this investigation is a story of the nature and academic impact of Social Darwinism that differs considerably from important accounts of Social Darwinism in AngloAmerican academia (Hofstadter, 1944; Hawkins, 1997). In contrast, the arguments here continue in the broadly revisionist tradition of Robert Bannister (1979), Greta Jones (1980), Donald Bellomy (1984), Mark Pittenger (1993), Paul Crook (1994) and others who have shown that political appeals to Darwinism in Britain and America were most frequently associated with 
anarchists, liberals and socialists. The label was used primarily by leftists to pin upon their opponents.

There was no self-declared school of Social Darwinists. Rather the term 'Social Darwinism' originally appeared in the course of an ongoing debate over the proper uses of biology for understanding society. In contrast, since the 1940s, it has been widely used to dismiss any use of biological ideas in the social sciences. The outcome is that 'Social Darwinism' is an ambivalent and misleading label.

Contrary to common supposition, it will be shown that the early use of the term 'Social Darwinism’ in Anglophone academic journals was highly infrequent and sporadic, and almost entirely disapproving of what the label was supposed to describe. The term disappeared from the principal academic journals in 1925 and reappeared in 1932, when it was used prominently in an additional manner, to describe analytical and analogical links between sociology and biology. Subsequently its use became much more frequent, with the war against Nazism and the appearance of Richard Hofstadter's classic book on Social Darwinism in American Thought (1944).

Hofstadter identified Social Darwinism not in terms of any school that used the term to describe its own ideas, but in terms of the usage of key phrases such as 'natural selection', 'struggle for existence', and 'survival of the fittest'. After Hofstadter the term 'Social Darwinism' was used not only as a general description for abuses of biology by the Nazis and others, but also as a means of sustaining the established separation between the social sciences and biology. Despite the decisive defeat of fascism in 1945, the use of the term rose inexorably and exponentially for the remainder of the twentieth century. It acquired mythological attributes, 
referring to a pre-1914 era when its use was assumed to be prevalent. At least as far as the Anglophone academic journals are concerned, this assumption is false.

Scholars after Hofstadter have shown that not only conservatives and nationalists used Darwinian arguments. In addition, anarchists, socialists and liberals deployed them extensively. Despite this, a widespread opinion remains that Darwinism has intrinsic, intractable and ideological problems for social science, and hence it should be banished from social science altogether (Hawkins, 1997). Powerful counter-arguments to this opinion have been presented elsewhere. The aim of this article is to trace neither the implications of Darwinism in the social sphere, nor the impact of ideas described by others as 'Social Darwinism'. Instead, the aim is to trace the dissemination, use and meaning of the term 'Social Darwinism' as it actually appeared in the academic journals of the time.

This essay takes advantage of JSTOR an electronic database of leading academic journals in anthropology, economics, general science, history, literature, philosophy, political science, population studies, sociology and other subjects, which has become available in the 1990s. These journals are almost entirely in English, and several date back to the time of Darwin. A search was made for the terms 'Social Darwinism', 'Social Darwinist' or 'Social Darwinists' in articles or reviews. ${ }^{4}$

The appearance of the concept in a book rather than a journal would often be flagged, as long as that book was sufficiently influential to be reviewed in a leading journal, and the review actually cited 'Social Darwinism'. The JSTOR search thus allows a more complete picture of uses of the 'Social Darwinism' in Anglophone academic discourse than hitherto possible. ${ }^{5}$ 
In the case of any journal article mentioning 'Social Darwinism' it is important to determine whether the author advocated or critiqued the doctrine that was given that label. In the case of a review, it is important to ascertain whether the author of the book under review advocated or critiqued such a doctrine, and whether the reviewer agreed or disagreed with the book author in that respect.

Section 2 of this article briefly reviews the historical background, by considering some names that might be associated with 'Social Darwinism', principally in the English-speaking world. This section should not mislead the reader into presuming that I am attempting an adequate or complete account of the impact of Darwinism in politics and social science. It simply provides a background to the main theme of this essay, which is in sections 3-7.

Section 3 analyses the use of the term 'Social Darwinism' in the Anglophone academic literature up to the outbreak of the First World War in 1914. Section 4 does the same for the period up to the Great Depression. Section 5 notes the changing meaning of the term in the period from 1932 to 1940. Section 6 shows how the Second World War gave an enormous boost to the use of the term in the academic literature. Section 7 briefly discusses sociobiology and Social Darwinism. Section 8 concludes the essay.

\section{Searching for Social Darwinism: Some Background Issues}

Who were the leading academic 'Social Darwinists' in America and Britain in the nineteenth century? If we take the standard literature on 'Social Darwinism' as a guide, then the names that spring up immediately are Herbert Spencer and William Graham Sumner. If we put the phrase 'Social Darwinism' in a standard web search engine, then the name of Spencer appears in 
profusion: Spencer is regarded as the foremost 'Social Darwinist' and Sumner as his American Deputy. There is no denying their impact. Sumner was a prominent professor at Yale University. Spencer had no academic position, but he was enormously influential in Anglo-American academia.

The names of Spencer or Sumner are often cited, but their works are little read. In fact, neither Spencer nor Sumner used the term ‘Social Darwinism'. It is only in retrospect and by association that they are deemed pioneers of an ill-defined creed given that name. It is true that Spencer promoted 'the survival of the fittest'. In fact, he originated the term. However, it was not until 1866, after the first edition of the Origin of Species had appeared, that Darwin was persuaded by Alfred Russel Wallace to use Spencer's phrase - rather than 'natural selection' - in key passages in that work (Waters, 1986, pp. 207-8). In truth, Spencer did not like being described as Darwinian because he believed that he had published a valid theory of evolution prior to Charles Darwin. Spencer (1893) argued that natural selection did not provide an adequate explanation of the evolution of species. In several key respects his doctrine was very different from that of Darwin and it was recognized as such at the time (Wiltshire, 1978; Hodgson, 1993).

Despite today being widely described as a 'Social Darwinist', there is relatively little Darwinism in Sumner's writings (Bannister, 1973, 1979; Smith, 1979). Sumner occasionally adopted Spencer's phraseology of the 'survival of the fittest' and less often Darwin's term 'natural selection', and used them in an imprecise exoneration of individualism, inequality and market competition. In his most important treatise, Sumner (1906) mentioned Darwin only once. Sumner’s disciple Albert Galloway Keller (1923, p. 137) remarked that his teacher 'did not give 
much attention to the possibility of extending evolution into the societal field.' Again, it is mainly in modern rhetoric that Sumner appears as a leading 'Social Darwinist.'

Broadly 'evolutionary' ideas appeared in famous works of the 1860s and 1870s by Henry Maine, Edward Tylor, Lewis Henry Morgan and several others. Some of these classic evolutionists distanced themselves entirely from Darwin’s work. Passing references to 'struggle,' 'fitness,' and even 'natural selection' in their books showed the influence of Darwinian or Malthusian terminology but no deep commitment to, or appreciation of, Darwinism (Bowler, 1988).

Other social scientists took a different theoretical line, arguing that Darwin's core theoretical principles of variation, inheritance and selection could be used to analyze the evolution of social systems, without suggesting that social phenomena could be explained entirely or principally in biological terms. The shared idea here was to see Darwinian theory as a general tool of analysis of evolving systems - unconfined to biology - rather than an ideological or political doctrine. ${ }^{6}$ Indeed, the political stances of many of these theorists happened to be quite different from what is today associated with 'Social Darwinism'. The British economist Walter Bagehot (1872) was one of the first to apply the core Darwinian theoretical ideas to the social sciences. On the political side, Bagehot defended liberal democracy and social reform. Henry Drummond (1894) similarly embraced Darwinian theory and emphasized the role of the cultural environment in human development. In accord with Darwin in his Descent of Man, Drummond saw the positive evolutionary role of human altruism and cooperation. David Ritchie (1896) - a Scottish philosopher of Fabian and liberal political views - argued that social institutions could be treated as units of Darwinian selection. Similarly, Thorstein Veblen (1899) called for the application of 
Darwinian principles to economics, wrote of 'the natural selection of institutions' and argued that socio-economic evolution was neither an optimizing nor a teleological process. Notably, despite their resolute applications of Darwinian concepts to the theory of social evolution, none of these authors has been widely and subsequently described as a Social Darwinist. ${ }^{7}$

A Russian scholar who also rigorously applied Darwinian principles of natural selection to the social domain was the anarchist Petr Kropotkin (1902). He argued that cooperation and mutual aid were exemplified among other species in nature, and thus they also apply to humankind. Furthermore, he attacked those that had used the term 'struggle for existence' to connote war or individualist competition. Kropotkin saw this ‘struggle for existence' as broadly and generally 'a struggle against adverse circumstances'. Kropotkin thus interpreted the concept in general terms, in a theoretical manner consistent with the authors mentioned in the preceding paragraph. ${ }^{8}$

Most of the early uses of the term 'Social Darwinism' emanated from Continental Europe, rather than from Britain or America. The earliest appearance of the term seems to be in an 1879 article in Popular Science by Oscar Schmidt, followed immediately by an anarchist tract published in Paris in 1880 entitled Le darwinisme social by Émile Gautier. Foreshadowing Kropotkin (1902), Gautier argued that the true application of Darwinian principles to human society meant social cooperation rather than brutal competition. However, unlike Kropotkin, Gautier used the term 'Social Darwinism' to criticize those who claimed to use Darwinian ideas to support capitalist competition and laissez faire. Following Gautier, others popularized the term in France (L. Clark, 1985). In 1882 Giuseppe Vadalà-Papale published Darwinismo naturale e Darwinismo sociale in Italy and helped to popularize the term in that country (Bellomy, 1984). 
The once fashionable French sociologist Gabriel Tarde (1884) was one of the few in academic circles who used the term 'Social Darwinism' approvingly. Tarde (1890) attempted to apply Darwinism to an analysis of imitative behavior in human society. But this usage was relatively primitive and innocent, without strong ideological connotations, and hence Tarde does not appear in modern demonologies of 'Social Darwinism'.

The early Continental European critics of misapplications of Darwinism were not tilting at imaginary windmills. For example, in Germany, the respected academic biologist Ernst Haeckel was an enthusiastic advocate of a Darwinism mixed with racist sentiments (McGovern, 1941; Gasman, 1971, 1998). Haeckel was not alone: several American followers of Darwin harbored racist, imperialist and sexist ideas. For example, Joseph Le Conte (1892) was President of the American Association for the Advancement of Science when he published a book arguing that the 'negroes' were an inferior and doomed race. The American anthropologist Daniel Shute (1896, p. 127) exclaimed that 'the Caucasian stands at the head of the racial scale and the Negro at the bottom.'

But such propositions are neither contained in, nor implied by, Darwin's own writings. What are arraigned today - mostly by critics - under the term ‘Social Darwinism’ are ideas that have either little connection with Darwinism or are not exclusively represented by it. Despite some claims to the contrary, a strong case has been made elsewhere that Darwin himself was neither a jingoist nor a racist (Richerson and Boyd, 2001). He was a progressive liberal. On his travels to South America he was outraged by human slavery and he criticized the treatment of native peoples by the Spanish and Portuguese. In 1882 he signed a petition protesting against the persecution of the Jews in Russia. He extolled neither selfishness nor competition. Referring to 
social cooperation, Darwin (1871, vol. 1, p. 162) wrote: 'Selfish and contentious people will not cohere, and without coherence nothing can be effected.' Darwin himself never used the term 'struggle for existence' as a justification for imperialism or war. The cavalier use of the term 'Social Darwinism' associates him with scientific and ideological doctrines that he never proclaimed. ${ }^{9}$

Not only did Spencer coin the phrase 'survival of the fittest' before Darwin, but also Thomas Robert Malthus inspired the term 'struggle for existence'. ${ }^{10}$ In this broad intellectual context, these phrases were used in a variety of ways. As Gertrude Himmelfarb (1959, p. 407) rightly noted, Darwinian ideas were associated with every conceivable political stance, from pacifism to militarism, from socialism to individualism, from liberalism to conservatism.

Social Darwinism has been linked with eugenics; but conservatives, liberals and socialists alike adopted eugenic policies. Eugenics - the policy of improving the human stock by controlling marriage and reproduction - found its advocates and its critics, but was infrequently described as 'Social Darwinism' until after the Second World War. ${ }^{11}$

If it were the case that the likes of Spencer or Sumner were regarded in Anglophone academia at the time as leading 'Social Darwinists', then we should expect some repetition or citation of this perception in the contemporary academic journals. In fact, no such citations are found. There is no clear evidence in pre-1937 Anglophone academic publications to support the current view that Spencer and Sumner were the acknowledged leaders of an ideological movement then described as 'Social Darwinism'.12

The academic citations in leading Anglophone journals prior to the 1940s tell a very different story, the narration of which is a principal purpose of this paper. It is relatively easy to find 
examples of racist, sexist, individualist, competitive, nationalist and imperialist sentiments in Anglo-American academia. It is much more difficult to show that they were widely described by supporters or opponents - as ‘Social Darwinism’ within those academic circles prior to the 1940s.

Of course, the fact that 'Social Darwinism' is the wrong label does not mean that there was no real substance to be labeled. Individualist, racist and imperialist ideas were evident in academia and elsewhere. However, the main burden of this article is to explore how these views became so labeled, the frequency of use of the label in the academic journals, how the meaning of the label changed, and to suggest on historical grounds that that the label is highly misleading.

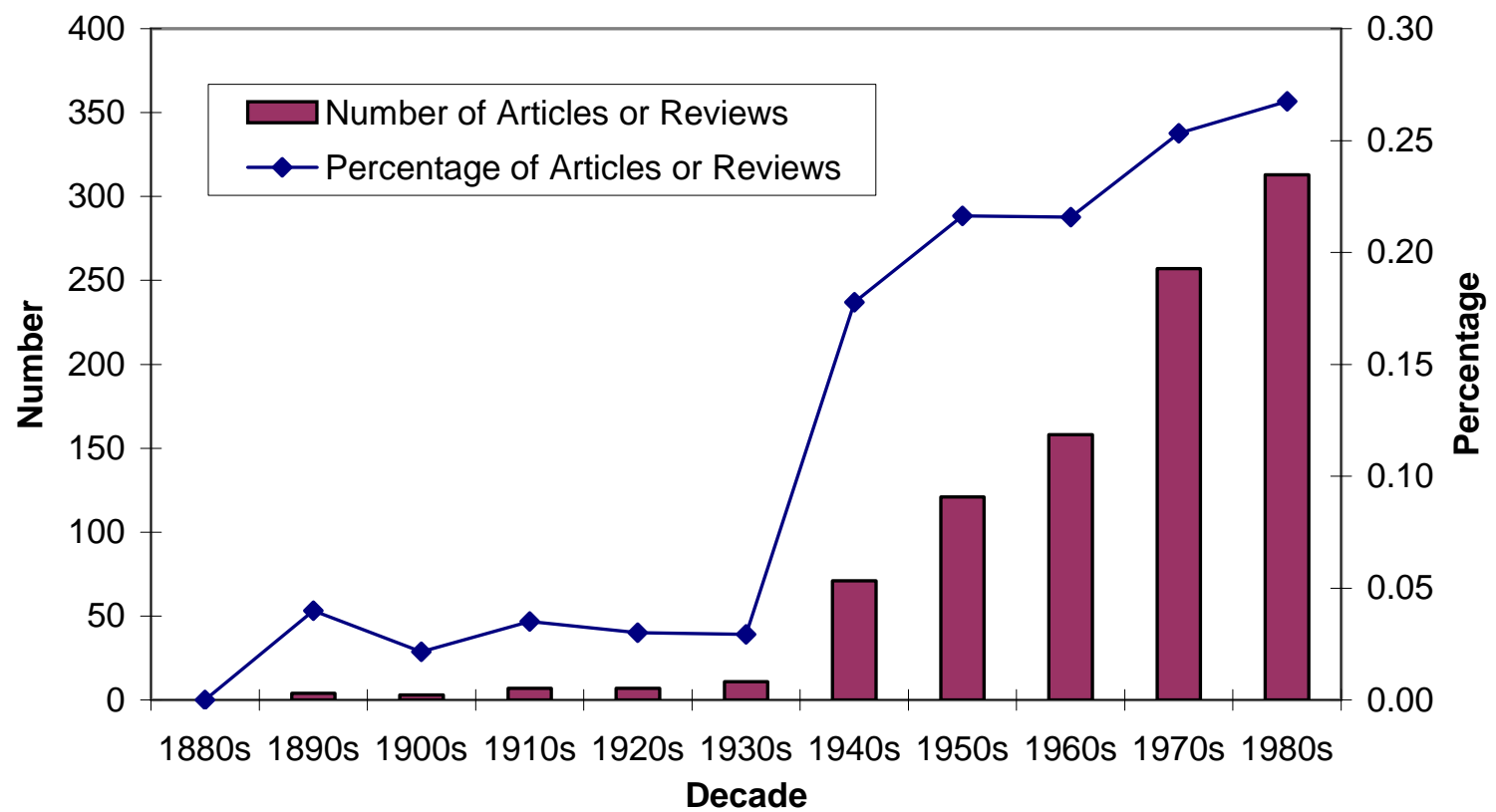

Figure 1: 


\section{The Number and Percentage of Articles and Reviews in the JSTOR Database in which "Social Darwinism” Appears}

\section{Citations to 'Social Darwinism’ Prior to the First World War}

Having prepared the ground, we can now turn to the history of the term itself, as it appears in the academic journals. Within the large JSTOR database of journals, references to 'Social Darwinism’ appear in articles or reviews only nine times prior to the outbreak of the First World War in $1914 .^{13}$ This is a surprisingly low number, especially as the JSTOR database dates from the 1850s. Over 42,000 articles and reviews appear in this database up to 1914. As shown in the Appendix, several leading journals were in existence by 1900, and several more were founded between 1900 and 1914.

By contrast, in articles or reviews in the JSTOR database up to and including 1914, there are 2,458 citations to 'Darwin' and 2,786 citations of the name 'Spencer'. ${ }^{14}$ While Darwin, Spencer and Sumner were highly cited, the term 'Social Darwinism' was hardly ever used. Furthermore, its principal but rare usage was in books critical of that doctrine, emanating from Continental Europe and often in languages other than English.

The first of these nine JSTOR citations to 'Social Darwinism' was in an 1895 review by the Harvard economist Frank Taussig of a book by the Italian socialist economist Achille Loria (1895). Taussig (1895, p. 537) praised Loria’s 'brilliant qualities ... wide learning ... skilful logic' and so on. He applauded Loria’s critical chapter on Social Darwinism and its demolition of 'current misapplications of the theory of natural selection to social phenomena.' The next three 
appearances of the term 'Social Darwinism' in the JSTOR database were all in 1897, including two approving reviews of Loria's (1895) book and a very short review by the American sociologist Albion Small of a book in French by Louis Wuarin (1896). Wuarin’s book was also critical of 'Social Darwinism' and Small did not dissent from this criticism. Hence all the four early appearances, up to and including 1897, endorse critiques of what is described as 'Social Darwinism’.

In the next appearance in JSTOR articles or reviews, the influential American sociologist Edward Alsworth Ross (1903, p. 448) wrote briefly of the 'master error of the social Darwinists', namely the mistaken belief that economic struggles had to be similar to biological struggles. Again, this citation is critical of 'Social Darwinism'.

We have to wait until 1907 for the next appearance of 'Social Darwinism' in articles or reviews in the leading Anglo-American academic journals. The term 'Social Darwinism' was used infrequently, and up to that date there was no single approving reference to any doctrine thus described. In addition, the (two Continental European) books that are reviewed were similarly critical of such an ideology. This is in remarkable contrast to some popular accounts of ‘Social Darwinism’ today.

The 1907 appearance of the term was in the American Journal of Sociology in an article by Collin Wells. Partly because the article itself is entitled 'Social Darwinism' it is worthy of more detailed discussion. This was the first use of the term in the title of an article in the JSTOR database. In addition, it is the only article or review found in this entire database clearly and explicitly advocating 'Social Darwinism' in any sense whatsoever. Wells (1907, p. 695) insisted, however, that by 'Social Darwinism' he did 'not mean those propositions of the doctrine of 
evolution which Darwin chiefly emphasized’! Instead, Wells broadly defined Social Darwinism as

the general doctrine of the gradual appearance of new forms through variation; the struggle of superabundant forms; the elimination of those poorly fitted, and the survival of those better fitted, to the given environment; and the maintenance of racial efficiency only by incessant struggle and ruthless elimination.

The final clause above is clearly contestable, and it will find no endorsement in Darwin's writings. With the important exception of this final clause, the remainder of this definition of Social Darwinism is so vague and broad that it would be consistent with the views of most scientists. None would deny 'the gradual appearance of new forms through variation', or some struggle in the face of scarcity, or the sad demise of those less fit to survive. Wells also saw survival in a 'given environment', rather than making the mistake of seeing fitness as contextindependent. Wells (1907) went on to use his invocation of 'rigorous selection' to argue for 'individualism' and against the collectivisms of trade unions and socialism. However, as Kropotkin (1902) and others have demonstrated, political individualism does not logically flow from Darwinism. In attempting to use biology to extol individualism, Wells was much closer to Spencer than Darwin.

The foremost American sociologist Lester Frank Ward had been invited to comment on Wells's paper when it was presented at the annual meeting of the American Sociological Society in 1906. Ward assumed that a paper entitled 'Social Darwinism' would be on the struggle among races and nations. To his surprise he found that Wells's paper was on eugenics. Ward (1907a, p. 709) wrote in a highly critical response: 
In Europe, especially on the continent, there has been much discussion of what they call 'social Darwinism.' Not all scholars there agree as to what it is, but certainly none of them use the expression in the sense that Dr. Wells uses it. ... Over there the discussion of this topic relates to two problems: first, the economic struggle, and, second, the race-struggle. Those who appear to defend this 'social Darwinism' are biologists mainly and not sociologists at all. Most of the sociologists attack it, as it is there understood. ... The great writers on race struggles never use the term 'social Darwinism,' but a number of sociologists have called them ‘social Darwinists’ without knowing what Darwin really stood for.

Ward affirmed that Social Darwinism was a term that was most prominent in Continental Europe, where it was used principally by critics of attempts to justify race struggles or wars in terms of the 'survival of the fittest'. In an article on 'social and biological struggles' published in the same year, Ward (1907b, pp. 289-90) argued that

the greater part of all that sociologists say on the subject is wide of the mark, and exhibits an almost complete failure on their part to understand the true nature of biological struggles.... The sociologists generally confound the so-called 'struggle for existence' with Darwinism, and very few of them have an adequate idea of what Darwin's phrase 'natural selection' means. ... [T] he sociologists ... have only a confused idea of the whole process which they imagine to constitute Darwinism.

Ward argued effectively that biology cannot be used to support laissez faire, race struggle, or national belligerence. He also protested against the association of Darwinism with these ideological views. Ward (1907b, pp. 292-3) wrote: 
I have never seen any distinctively Darwinian principle appealed to in the discussions of 'social Darwinism.' ... I wish to protest in the strongest possible terms against the application of the term Darwinism to race struggle. I know of no ethnologist, historian, or sociologist among those who see the real effect of the struggle of races, who has accepted this designation for that law. ${ }^{15}$

The next appearance of 'Social Darwinism' in the leading Anglophone academic journals was in 1911 in a review of a book by the Russian-born liberal pacifist Jacques Novicow entitled $L a$ critique du darwinisme social (1910). Novicow himself identified a vague doctrine called 'Social Darwinism' and blamed it for imperialism and war, although he noted that Darwin's own views were different. The reviewer was sympathetic to Novicow's anti-war sentiments. Novicow's text caused a flurry of further references to ‘Social Darwinism’ in the Anglophone journals.

We may summarize the position up to 1914, as evidenced by the leading Anglo-American academic journals:

- The use of the term ‘Social Darwinism’ was very rare in these journals.

- Generally, articles or reviews that mentioned 'Social Darwinism' in these journals disassociated themselves from the doctrines then associated with the term. The only exception was Wells (1907), who endorsed the term but used it in a distinctive manner, to refer to his version of eugenics. There is no cited evidence that advocates of race struggle or imperialist war widely used the term. No article or review that mentioned 'Social Darwinism' in leading Anglophone journals endorsed imperialism or war. With the single exception of Wells (1907), none promoted racist views. 
- Instead, all the available evidence suggests that the predominant usage of the term 'Social Darwinism’ was by Continental European socialists, anarchists, pacifists and radicals who were critical of ideologies of capitalist competition, imperialist war, or racial struggle. The works that had the most impact in promoting the term in leading Anglophone journals were by Achille Loria (1895) and Jacques Novicow (1910).

- $\quad$ Despite the influence of Spencer and Sumner in the Anglophone world, the term 'Social Darwinism' was not applied to their views in these journals.

\section{Citations to 'Social Darwinism’ from the Great War to the Great Depression}

Twelve JSTOR citations to 'Social Darwinism' appeared in six articles and six reviews from the outbreak of the First World War in 1914 to the Great Crash in 1929. None supports any purported ideological content of the term 'Social Darwinism'. The twelve citations are dominated by the reality of war and a concern for peace. Witnessing the greatest human slaughter in history, progressive and radical academics reacted against the belligerent rhetoric of 'race struggle' and the 'survival of the fittest'.

Two 1917 reviews were of the book by the American pacifist George Nasmyth (1916), which criticized 'Social Darwinist' justifications of war. In the midst of nationalist jingoism and carnage in Europe, the reviewers were sympathetic to Nasmyth's pacifist sentiments. In an influential volume of that time, the American philosopher Ralph Barton Perry (1918) argued that ideas of racial superiority and the natural status of conflict had been used to justify the war. Perry attacked all associations between biology and the social sciences. Darwinism was accused of a circularity 
of logic and a 'strong tendency to favor the cruder and more violent forms of struggle, as being more unmistakably biological' (Perry, 1918, p. 145).

In a similar vein, S. J. Holmes (1919, p. 21) noted in an article the 'perverted Darwinism' that upheld 'that competitive struggle is necessary for the progressive evolution of men.' For him this was a fundamental error 'too commonly found in the writings of the social Darwinist school.' In promoting social reform, Holmes urged the importance of education. Holmes accepted eugenics but rejected Social Darwinism. He described the anti-eugenicist Benjamin Kidd as 'a prominent social Darwinist'. Holmes also cited Spencer, but did not describe him in the same manner. In another article, in the following year, Erville Woods (1920, p. 3) wrote that sociology

has been extravagant in its professions of indebtedness to biology. Many absurdities in social theory have masqueraded in the borrowed trappings of biological conceptions. The so-called biological analogy is a case in point. Much more pernicious was the attempt to base an ethics of rapacity and greed upon what was ignorantly called social Darwinism.

This statement by Woods was prescient. He was fully aware that the label of 'Social Darwinism' was 'ignorantly' applied. Yet in worrying about the abuse of 'Darwinism' to support 'an ethics of rapacity and greed', Woods followed Perry (1918) by suggesting that the solution is not to correct such abuses and misconceptions, but to end all theoretical intercourse between sociology and biology. Eventually, the majority of sociologists adopted this strategy. It is akin to a policy of ending all conversation, simply because some people speak lies.

In 1921 Gregory Zilboorg (1921, p. 399) implausibly described Marxism as 'economic and social Darwinism.' Also the prominent American sociologist Harry Barnes (1921) noted without much further comment the attacks of Novicow and others on the 'so-called "social Darwinism"” 
of Ludwig Gumplowicz and Heinrich von Treitschke. Barnes’s article was the first item in the JSTOR database to mention both 'Social Darwinism’ and the name of William Graham Sumner. But Barnes did not then describe Sumner as a Social Darwinist.

A 1922 review briefly noted without disapproval a brief short attack on Social Darwinism. An article by Clarence Case (1922) criticized attempts to justify war as an extension of instinctive behavior. A review of 1924 noted without dissent a criticism of 'Social Darwinism' in a book entitled The Problem of War and Its Solution (Grant, 1922).

Clearly, from 1914 to 1924, the issue of war and its aftermath dominated these twelve citations of 'Social Darwinism'. Then, remarkably, not long after the dust of the First World War settled, the term disappeared from the Anglo-American academic journals. In the years from 1925 to 1931, the term 'Social Darwinism' did not emerge in this literature, despite global economic strife and rising fascism and anti-Semitism in Europe. Its next appearance - in 1932 - is highly significant, not least because of its remarkable absence for the preceding seven years.

We may again summarize the position, this time from 1914 to 1931, in the leading AngloAmerican academic journals:

- $\quad$ The term 'Social Darwinism’ remained very rare, and it simply disappeared from these journals from 1925 to 1931 inclusive.

- All articles or reviews that then mentioned 'Social Darwinism' in these journals disassociated themselves from the doctrines then associated with the term. 
- Critiques of 'Social Darwinism' in these journals prominently associated the term with doctrines of nationalism, imperialism or war. Strong anti-war sentiments prevailed in the academic literature that addressed this issue.

- Neither Spencer nor Sumner was then described as a 'Social Darwinist' in these journals. ${ }^{16}$

\section{Revival and Metamorphosis: 'Social Darwinism' from 1932 to 1940}

The author of the re-appearance of the term 'Social Darwinism' in the academic journals was no less than Talcott Parsons (1932) - the most influential American sociologist of the twentieth century. His used the term as a tool within his grand project to rebuild his discipline, to help fix the supposed boundaries of good and bad sociology. In a long article on Alfred Marshall, Parsons mentioned Social Darwinism twice. Parsons (1932, p. 325) briefly noted the application of Darwinian concepts of variation and selection to social evolution. Then in a footnote he wrote: 'The whole line of thought uppermost in this "Social Darwinism," is closely identified with the "scientific" aspects of the doctrines of Natural Law. Its emphasis is on the inexorability of social determinism.' But Parsons failed to name any proponent of this 'line of thought'.

Despite the typically cryptic elusiveness of this passage, Parsons extended the usage of 'Social Darwinism' from its previous ideological associations to anyone who believed in 'the application of Darwinian concepts of variation and selection to social evolution'. But it is not clear whom he had in mind. As I have argued elsewhere (Hodgson, 1993, 2004), rigorous attempts to apply Darwinian theoretical principles of variation and selection to socio-economic evolution are extremely rare. With its re-introduction by Parsons, following the precedents of Perry (1918) and 
Woods (1920), the meaning of the term Social Darwinism began to change. It was applied not exclusively to doctrines of race struggle or war, but to any application of Darwinism or related biological ideas to the study of human society. ${ }^{17}$

We shall quickly pass over Parsons's disapproving, clumsy and imprecise references to the 'scientific' aspects of 'Natural Law', and to 'the inexorability of social determinism.' What is being disapproved of, and what alternative may exist, is far from clear. In another footnote, Parsons (1932, p. 341) wrote: 'Pareto, like Marshall and Weber, sharply repudiates what he calls "social Darwinism."” But no textual references are given. We have to turn to the later Structure of Social Action to find the relevant misgivings of Pareto and Weber. As for Marshall, there is no repudiation of Social Darwinism in his works, and Parsons (1937) cited none. Although Marshall (1890) mentioned Darwin a few times, it was not in repudiation. In fact, Marshall was an explicit devote of the works of Spencer (Thomas, 1991; Hodgson, 1993; Laurent, 2000), who today is widely but wrongly described as a Social Darwinist! Parsons's standards of scholarship were somewhat defective, to say the least.

In the academic journals, two years later, Parsons returned to the fray, determined to depict 'Social Darwinism' as a living adversary of his brand of social science. He stretched the usage of the term to cover methodological as well as ideological views. Parsons (1934, p. 524) thus wrote: 'As the history of the great body of thought sometimes called "Social Darwinism" amply shows, the radical positivistic position leads directly to the view that these conditions are the decisive factors in social life.' By 'these conditions' Parsons (p. 523) meant 'man's non-human environment' as examined by 'biology and psychology’. However, as noted elsewhere (Hodgson, 2001), Parsons's understanding of the term 'positivism' was highly idiosyncratic, and had little if 
anything to do with the concept as invented and defined by Auguste Comte. By 'positivistic' thought, Parsons (1934, p. 513) meant the notion of using the methodology of 'physical science ... as a standard for the measurement of the rationality of human action.' The 'positivistic' approach was said to involve an 'emphasis on scientific "objectivism"' and the neglect of individual purposes or ends in explanations of human action. What Parsons seemed to be suggesting, in a rather convoluted way, was that 'Social Darwinism' over-emphasized natural conditions, to the exclusion of human society and individual intentionality. But again he gave no references to support this claim. Once again, Parsons used the rhetoric of 'Social Darwinism' to exclude or downplay insights from biology or psychology within social science.

The material from these two articles by Parsons $(1932,1934)$ was recast in his monumental Structure of Social Action (1937). This book mentions ‘Social Darwinism’ several times, and in a similar vein. It became clear that Parsons was trying to change the character and focus of sociology, and to establish strong barriers between sociology and other disciplines, particularly economics, psychology and biology (Camic, 1987, 1991; Hodgson, 2001). In particular, Parsons wanted to prevent biologists from incursion into areas of research that should belong to his new sociology. Parsons was thus the most important inventor of the modern demonology of Social Darwinism in social science.

Another mention of Social Darwinism took a subtly contrasting line. In a sympathetic double review of a biography of Veblen (Dorfman, 1934) and a collection of Veblen's writings (Mitchell, 1936), Read Bain (1934, p. 486) approvingly referred to Veblen as 'the Darwin of economics ... he made a Darwinian analysis of culture more radical (fundamental) than any achieved by the so-called "social Darwinists." They proceeded by specious analogy; he by 
intensive analysis.' But despite Veblen's explicit attempt to construct a 'post-Darwinian' economics, Bain did not describe Veblen as a Social Darwinist. Bain (1940, p. 257) warned briefly and vaguely of the dangers of 'social Darwinism and biological determinism.' But again, Veblen luckily escaped condemnation. Like Parsons, Bain saw Social Darwinism as a scientific as well as an ideological stance.

In the same year as Parsons' milestone article, the aforementioned University of California biologist Holmes (1932, p. 202) associated Social Darwinism with ideas of 'group selection ... mutual aid, social sympathy, self-sacrifice and ... cooperation'. This was redolent of Kropotkin, and very different from the usage by Parsons. Also in that year, Barnes (1932, p. 544) mentioned the contention of the 'so-called "Social Darwinists" that "war had been the chief constructive process in the evolution of humanity.' Barnes went on: 'It must be pointed out, however, that Darwin himself never sanctioned any such sociological interpretation of his evolutionary theories, and the title "Social Darwinism" was appropriated by this group without the approval of Darwin himself.' As well as rightly challenging the Darwinian pedigree, Barnes (p. 548) also noted that 'Social Darwinism' and other 'interests and activities as characterized biological sociologists thirty years ago have now become thorough anachronisms in the field.'

This treatment of Social Darwinism as a thing of the past was evident in some other journal citations. Four articles and two reviews appearing from early 1936 to February 1940 briefly mentioned Social Darwinism in the context of historical discussions of the development of ideas in the late nineteenth century, in Germany, Japan, Yugoslavia and elsewhere. Unlike Bain and Parsons, but in accord with Barnes's (1932) proclamation of the earlier demise of Social Darwinism in academic sociology, they did not identify Social Darwinism as a present threat. But 
with the events of the next few years, and the intervention of Parsons and others, the situation was to change, as ‘Social Darwinism’ was perceived increasingly as a current menace.

A 1937 citation of 'Social Darwinism' is of some additional significance, because it is the very first description in the JSTOR database of Spencer as a Social Darwinist. In a book review, Leo Rogin (1937, p. 413) reported the view of the Russian Marxist B. I. Smoulevitch: 'While the doctrine of social Darwinism played an important part in Herbert Spencer's formulation, its combination, more recently, with the racial theories makes the latter type quite the most vicious'. In this manner, the description of Spencer as a Social Darwinist traveled into the Anglophone academic journals.

Clearly, with its re-appearance in the $1932-1940$ period, the term 'Social Darwinism' assumed an additional and subsequently enduring connotation. Previously it had been associated with the ideologies of individualism, race struggle and imperialism. In the works of Parsons (1932, 1934, 1937) and a few others, it became additionally connected with work within science that proposed partial or complete explanations of social phenomena in biological terms, or used biological analogies, or found ideas from biology useful in the social domain.

Accordingly, in this context, Spencer became associated with Social Darwinism, alongside unwarranted conflations of the ideological with the scientific. Spencer himself had pioneered his own unjustified conflations of ideology and science. Note also that the first JSTOR cited description of Spencer as a Social Darwinist came from a Marxist source. The idea that all science comes with inherent ideological tags is commonplace in Marxian literature. So arose the myth that Spencer had promoted something that was widely described by him or his 
contemporaries as Social Darwinism. This myth was given an enormous boost in the next period, when Sumner's name was bracketed with Spencer's. ${ }^{18}$

\section{6. 'Social Darwinism', the Second World War, and the Subsequent Explosion}

In May 1940 the Nazis invaded Holland, Belgium, Luxemburg and France. In the following months the Battle of Britain was waged in the air. Against Nazi belligerence, pacifist sentiments seemed less viable than in the First World War. Consequently, after 1940 the literature criticizing 'Social Darwinism' concentrated more on the ills of fascism and racism, and less on earlier 'Social Darwinist' attempts to justify war.

In an article in the Political Science Quarterly, Evalyn Clark (1940) alleged that the German economist Adolf Wagner (who died in 1917) was one of the 'founders' of National Socialism. Wagner was described as a nationalist, imperialist, racist and Social Darwinist. William McGovern (1941) published a timely book entitled From Luther to Hitler: The History of Fascist-Nazi Political Philosophy. In JSTOR journals from 1941 to 1944, one article and four reviews noted approvingly this book’s critique of 'Social Darwinism’.

In another citation, Joseph Gittler (1942, p. 383) wrote: 'Following Spencer, a group of thinkers who have been called "social Darwinists" formulated another theory of social evolution. Included in this group were Benjamin Kidd, Jacques Novicow, G. Vacher de Lapouge, and Otto von Ammon.' After its 1937 precedent, this is the second JSTOR description of Spencer as a Social Darwinist. Its author ignorantly described Novicow as a devotee of Social Darwinism. In fact he was a leading critic. ${ }^{19}$ 
Up to and including 1942, the maximum number of JSTOR citations to Social Darwinism in any single year was three. The annual average from 1895 to 1942 inclusive was 0.85 citations. The United States entered the War in December 1941, and after a year had passed the citation rate leapt upwards. There were five citations in 1943, twelve in 1944 and sixteen in 1945. This quantitative explosion prohibits detailed discussion of all references.

However, several of the citations to Social Darwinism during the Second World War still treated it as a historical phenomenon, existing principally before the First World War. But some warned of the dangers for the present. In such a vein, a reviewer noted 'the slashing assault on social Darwinism' in a work by Lewis Mumford (1944). Two reviews, by Raymond Nixon and by the American economist Frank Knight, commended the critique of Social Darwinism by Laurence Stapleton in his 1944 book Justice and World Society.

Subsequently the deluge. In 1944 Hofstadter published his classic Social Darwinism in American Thought. It had previously appeared as a Columbia University PhD thesis in $1938 .{ }^{20} \mathrm{In}$ his description of American Social Darwinism, Hofstadter lumped together a host of diverse figures, including Spencer, Sumner and Ward. For Hofstadter, Social Darwinism was a reactionary creed, largely associated with the promotion of racism, nationalism and competitive strife. The skills of a great historian were deployed in the ideological war effort against fascism and genocide.

The first review of this influential treatise appeared in the academic journals in December 1944. In all, three reviews of this work appeared in 1944, seven in 1945, and two in 1946. The reviews were generally favorable. Ironically, Keller (1945) gave the book a positive review. Keller was a follower of Sumner, and like his teacher has himself since been dubbed a 'Social 
Darwinist'. Citations to Hofstadter's book were even more plentiful than its reviews, particularly in later years. It became the seminal treatise on Social Darwinism, and it has driven the discussion of the topic ever since.

The Second World War put the concept of Social Darwinism in a position of prominence that it had never previously attained. The menace of Nazism stimulated critiques of Social Darwinism. At the same time, Parsons's reconstruction of sociology gained influence and popularity (Camic, 1991; Hodgson, 2001). He built a Chinese Wall, with the social sciences on one side, and biology and psychology on the other. ${ }^{21}$ Growing citations to the menace of 'Social Darwinism' helped to reinforce this wall, by pointing to the barbarian abuses of biology in recent memory.

As shown in Figure 1 above, references to Social Darwinism in the Anglophone literature grew exponentially after the 1940s. In terms of the percentage of all JSTOR articles and reviews, its appearance increased substantially after 1944. Hofstadter's (1944) work both expressed and sustained critical interested in this new version of the demon creed. From 1944 to 1969 inclusive, Hofstadter’s book was mentioned in no less than 23.6 per cent of all JSTOR articles or reviews citing Social Darwinism. The book was revised and reprinted several times. In 1968 it reached its fifteenth reprinting. It remains by far the single most important reference on the topic. From Hofstadter (1944) to the present day, mentions of 'Social Darwinism' were plentiful but entirely dismissive and critical.

Another effect of the extension in meaning of Social Darwinism was to associate it much more strongly with the figures of Spencer and Sumner. As noted above, their work was rarely described as Social Darwinist until the 1930s. In the JSTOR literature, Spencer was first portrayed as a Social Darwinist in 1937, and Sumner was not so described before the appearance 
of Hofstadter's $(1941,1944)$ work. After 1944, the depiction of Spencer and Sumner changed dramatically. From 1944 to 1959 inclusive, Spencer was cited in 37.6 percent, and Sumner in 23.6 per cent, of all JSTOR articles mentioning Social Darwinism.

Remarkably, neither Spencer nor Sumner was described in the JSTOR database as a 'Social Darwinist' prior to the 1930s. An explanation for this shift is as follows. While they supported individualism and market competition, Spencer and Sumner were strong critics of militarism and imperialism. In contrast, especially around the time of the First World War, the majority of the rare uses of the term Social Darwinism associated it with militarism and war. Even when criticized, Spencer and Sumner were typically put in a different camp. Subsequently, with the rise of Nazism, intellectuals were won over to the idea of an anti-fascist war. Consequently, critics of 'Social Darwinism' were then less likely to adopt an anti-war stance. One barrier preventing the inclusion of Spencer and Sumner in the 'Social Darwinist' camp was removed. The fact that they were not Darwinians was simply ignored. Parsons's wide definition of Social Darwinism, including anyone who applied biological ideas in the social sciences, also helped to admit Spencer and (to a lesser extent) Sumner. Once they had been thus labeled, just prior to the explosion in use of the term in the 1940s, the label stuck. Spencer and Sumner were late coming 'Social Darwinists' as a result of mutating meanings, historical flukes and compelling events. ${ }^{22}$

We may again summarize the position, this time from 1940s to the present, in the leading Anglo-American academic journals:

- The Second World War greatly amplified the usage if the term 'Social Darwinism', to unprecedented levels. 
- Articles or reviews that mentioned 'Social Darwinism' in these journals generally disassociated themselves from the doctrines then associated with the term.

- Following Parsons (1932, 1934, 1937) and others, the term 'Social Darwinism' became prominently associated with particular methodological and scientific, as well as ideological views. In particular, it was used to exclude or downplay the use of insights or analogies from biology within social science.

- Strong anti-fascist and anti-racist sentiments pervaded the citations of 'Social Darwinism' in these journals. But, in contrast to the period before 1940, the term 'Social Darwinism' was less frequently associated with the advocacy of war. It was more prominently used to connote competition, racism and the use of biology in social science.

- Accordingly, and contrary to almost all earlier accounts in the Anglophone academic journals, Spencer and Sumner began to be widely described from the 1940s as leading 'Social Darwinists'.

\section{Sociobiology and Social Darwinism}

Figure 1 shows an increase in the percentage of articles or reviews citing Social Darwinism in the 1970s and 1980s. To what extent is the increase due to the publication of Edward Wilson's Sociobiology in 1975, and to the explosion of controversy over this new discipline? ${ }^{23}$

What concerns us here is the role that sociobiology, and the reaction against it, played in reinvigorating the phobia against Social Darwinism. Wilson $(1975,1978)$ himself rejected the label of 'Social Darwinism'. There is no evidence that he is a racist or a fascist, although he has been accused of these sins. Furthermore, his passionate environmentalism would not readily align 
him with exponents of unbridled capitalist competition (Segerstrale, 2000). Alarmingly, some neo-fascist groups in Europe have adopted sociobiology as a slogan, but fascism is not known for its pursuit of accuracy or truth.

The publication of Wilson's work created a storm of controversy. In America, the 'Sociobiology Study Group of Science for the People' entered the fray, declaring immediately that Wilson had opened the door to racism and other doctrines that they explicitly associated with ‘Social Darwinism’ (Allen et al., 1976). Other authors, including in the JSTOR literature, have subsequently repeated this characterization of Wilson as a Social Darwinist.

If Social Darwinism simply means the application of Darwinian ideas to social phenomena, then Wilson stands condemned, along with Kropotkin, Ritchie, Veblen and many modern writers who have also applied Darwinian principles of variation, selection and inheritance to socioeconomic change. In contrast, if Social Darwinism means the use of Darwinism to justify individualist, conservative or racist views, then Wilson must be acquitted. Alternatively, if Wilson is charged with claiming to explain human social phenomena entirely in biological terms, then he must also be acquitted, partly on the grounds of his explicit and repeated claims to the contrary. But if Wilson is charged with exaggerating the possibility of using biology to explain human behavior then there still remains a strong case against him to be answered. ${ }^{24}$ It all depends on the precise charge. The imprecise accusation of 'Social Darwinism' is of little help.

Using the methodology employed in this essay, we can assess the impact of sociobiology on the use of the use of the 'Social Darwinism' term. From 1975 to 1979 inclusive, seven JSTOR articles or reviews mention both Social Darwinism and sociobiology. In the 1980s, a further 33 articles or reviews mentioned both these terms. It seems that the appearance of sociobiology in 
1975 can partly, but not wholly, account for the increase in usage of the term Social Darwinism in the 1970s and thereafter.

Inspecting these articles and reviews, it is clear that dismissals of sociobiology in terms of being described as a revived 'Social Darwinism' are in a minority. Nevertheless, a widespread ignorance of the true historical meaning of the term Social Darwinism still prevailed. Despite the scholarly contributions of Bannister and others, many are unaware of the way in which the term had actually been used before the 1930s. ${ }^{25}$ The subsequent historical shifts in the meaning of the term are also unappreciated.

The influence of Parsons and others remains, in using the term to condemn any attempt to explain any social phenomenon in biological terms. The conflation of ideology with science greatly impaired the post-1975 debate concerning the merits or demerits of Wilson's sociobiology. If the problem with sociobiology is its biological reductionism, then the problem should be described as such. The description of sociobiology as Social Darwinist adds further confusion to an already enraged debate.

\section{Conclusion: The Mythology of 'Social Darwinism'}

I now summarize the key results of this study of the appearance of the term 'Social Darwinism' in the Anglophone academic journals. Its use, at least in this context, was very rare up to 1924 and nonexistent from 1925 to 1931 inclusive. After some appearances in the 1930s, its frequency of use began to increase exponentially after 1940 . However, with the single exception of Wells (1907), the phrase was used by critics who disassociated themselves from the doctrines then associated with the term. 
Another result is that a shift in meaning has been detected by comparing its earlier and rare appearances up to 1924 with those more abundant after 1940. During the First World War, 'Social Darwinism' was used most frequently to describe ideologies of militarism, nationalism and imperialism. Accordingly, in the literature surveyed, neither Spencer nor Sumner was then described as a Social Darwinist. Despite their support for capitalist competition, these authors were anti-militarist and anti-imperialist.

The term re-appeared in the Anglophone academic journals in an article by Parsons (1932), who promoted a different meaning of the term, using it in part to describe any attempt by social scientists to utilize ideas from biology. Also in the 1930s, Spencer and Sumner began to be described as Social Darwinists in these journals.

During the Second World War the use if the term 'Social Darwinism' increased to unprecedented levels. In the context of the Allied war effort against fascism, Hoftstadter's (1944) classic critique of 'Social Darwinism' downplayed the previous association of the term with militarism and accented its other connotations. Hofstadter also added impetus the argument of Parsons that the social sciences should sever all links with biology. He also portrayed Spencer and Sumner as leading 'Social Darwinists', and the description stuck. He lumped together all sorts of views under the vaguely defined label 'Social Darwinism' and failed to note the crucial differences in both analysis and orientation between Darwinism and Spencerism. In contrast to the period before 1940, the term 'Social Darwinism' was no longer prominently associated with the advocacy of war. It was more prominently used to connote competition, racism and the use of biology in social science. 
These results are consistent with the revisionist accounts of Bannister (1979), Donald Bellomy (1984), and others. They support the verdict that the label of 'Social Darwinism' has harbored a number of myths. The label associated Darwinism with a number of particular ideological propositions that do not follow logically from this scientific theory. Such misinterpretations were aided by the limited assimilation of Darwinian theory prior to the First World War (Bowler, 1983, 1988).

Instead, if rarely, the term was originally and principally applied by anarchists, socialists and pacifists to varied political views that they opposed (Bannister, 1979). By the 1940s, widespread political sentiments, from anarchists such as Kropotkin, through liberal free traders such as Spencer and Sumner, to more militant nationalists, and racists such as Haeckel, were all conflated together under the single, misleading label of Social Darwinism.

A theoretical position cannot itself be completely evaluated simply in terms of the political views of its proponents. On the contrary, no matter how distasteful (or attractive) the political views of individuals proposing a theoretical analysis, this has no bearing on whether the theoretical explanation of cause and effect is actually true or false. The choice of priorities for scientific research is partly and unavoidably a political decision. But the scientific evaluation of scientific theories or results is not.

Not only have multiple insights been rejected on the grounds of the obnoxious political views (perceived or actual) of their proponents, but also a whole tradition of attempting to apply Darwinian ideas to social science, or to gain insight from biology concerning the human condition, has been consigned to obscurity. This is despite the fact that the political views of many of the promoters of evolutionary ideas in the social sciences - Kropotkin, Ritchie, Veblen 
and Ward included - were far from individualist or conservative. All have been casualties of the ongoing campaign against 'Social Darwinism', and the attempt to remove any discussion of biology from social science.

Another, related myth was to see any close relationship between biology and the social sciences as inevitably negative or unsound. This myth gained strength in the 1930s when AngloAmerican sociology tried to break entirely from biology. To consolidate and justify its independence and isolation from the natural sciences, it exaggerated and misrepresented the previous impact of Darwin's ideas on the social sciences. Given further impetus by the horrors of Nazism, the effect of the myth was to terminate much interdisciplinary conversation between the social sciences and biology. This had a dramatic and adverse effect on the development of the social sciences. For example, by simply assuming that it was all due to nurture rather than nature, psychologically-informed examinations of the nature and limits of human mental capacities on social behavior were pushed to one side (Cravens, 1978; Degler, 1991; Weingart et al. 1997). Furthermore, the early idea of applying Darwinian evolutionary principles to social evolution (in the manner of Ritchie, Veblen and others) was ignored for much of the twentieth century (Campbell, 1964; Hodgson, 1999, 2002, 2004).

Overall, the label of 'Social Darwinism' is unhelpful and misleading. In its established context it serves the purpose of tolerating 'Darwinism' in biology but entirely excluding it from social science. It lumps together and dismisses a whole host of varied and important developments in the 1870-1914 period that in some way developed or maintained links between biology and the social sciences, including the careful use of biological analogies in the analysis of social evolution (Hodgson, 2004). We should be critical of racist, sexist and imperialist ideologies, but 
these emanate neither from the act of linking biology with the social sciences, nor from the principles of Darwinism.

The woods can be dangerous. So we might tell children stories of woodland beasts or bogeymen, to warn them away from the forest. Similarly, prevailing accounts of 'Social Darwinism’ have been invented as bogeyman stories, to warn all social scientist away from the darkened woodland of biology. We are told that any use of ideas or analogies from biology in the social sciences is unsafe. We are warned not to stray into that biological zone, for terrible things might happen, as they surely happened before. But scientists should not be treated like children. And some accounts of the history of 'Social Darwinism' are false or misleading in several crucial details.

It would be better if the use as a descriptive term of the highly ambiguous and imperfectly grounded phrase ‘Social Darwinism’ were discontinued. It would be clearer and more effective if authors criticized more directly the readily identifiable and less ambiguous ideological ills of racism, sexism, imperialism or eugenics. If biological reductionism is also to be a target, then let us describe it by its name. If some promoters of sociobiology or evolutionary psychology attempt to explain the social entirely in biological terms, then let us critically evaluate that methodology, and identify the irreducible properties of the social domain. Let us stop telling false histories, and henceforth call things by their proper names. 


\section{Appendix: List of journals searched up to and including 1989, with}

\section{date of first inclusion}

Some of these journals changed their names, in which case both the old and the new names are listed.

Academy of Management Journal (1963), Accounting Review (1926), Administrative Science Quarterly (1956), African Affairs (1944), African Historical Studies (1968), African Studies Bulletin (1958), American Antiquity (1935), American Economic Association Quarterly (1908), American Economic Review (1911), American Historical Review (1895), American Journal of Archaeology (1885), American Journal of Botany (1914), American Journal of International Law (1907), American Journal of Mathematics (1878), American Journal of Philology (1880), American Journal of Political Science (1973), American Journal of Semitic Languages and Literatures (1895), American Journal of Sociology (1895), American Literature (1929), American Mathematical Monthly (1894), American Midland Naturalist (1909), American Naturalist (1867), American Political Science Review (1906), American Quarterly (1949), American Slavic and East European Review (1945), American Sociological Review (1936), American Speech (1925), American Statistician (1947), Annals of Mathematical Statistics (1930), Annals of Mathematics (1884), Annals of Probability (1973), Annals of Statistics (1973), Annals of the Association of American Geographers (1911), Annals of the Missouri Botanical Garden (1914), Annual Review of Anthropology (1972), Annual Review of Ecology and Systematics (1970), Annual Review of Sociology (1975), Anthropology Today (1985), Applied Statistics (1952), Archaeological Reports (1954), Asian Survey (1961), Australian Journal of Chinese 
Affairs (1979), Background on World Politics (1957), Biennial Review of Anthropology (1959), Biometrics (1947), Biometrika (1901), Biotropica (1969), Black American Literature Forum (1976), Botanical Gazette (1876), British Journal for the Philosophy of Science (1950), British Journal of Sociology (1950), Brittonia (1931), Bulletin of African Studies in Canada (1963), Bulletin of the American Geographical Society (1901), Bulletin of the School of Oriental and African Studies (1940), Bulletin of the School of Oriental Studies (1917), Bulletin of the Torrey Botanical Club (1870), Callaloo (1976), Canadian Journal of African Studies (1967), Canadian Journal of Economics (1968), Canadian Journal of Economics and Political Science (1935), China Quarterly (1960), Classical Philology (1906), Classical Quarterly (1907), Classical Review (1887), College Composition and Communication (1950), College English (1939), Comparative Literature (1949), Comparative Politics (1968), Comparative Studies in Society and History (1958), Contemporary Sociology (1972), Contributions to Canadian Economics (1928), Coordinator (1952), Current Anthropology (1959), Demography (1964), Ecological Monographs (1931), Ecology (1920), Econometrica (1933), Economic Geography (1925), Economic History Review (1927), Economic Journal (1891), Economica (1921), Eighteenth-Century Studies (1967), ELH (1934), English Historical Review (1886), Ethics (1938), Ethnohistory (1954), Evolution (1947), Family Coordinator (1968), Family Life Coordinator (1959), Family Planning Perspectives (1969), Far Eastern Quarterly (1941), Far Eastern Survey (1935), French Historical Studies (1958), French Review (1927), Geografiska Annaler (1919), Geographical Journal (1893), Geographical Review (1916), German Quarterly (1928), Greece and Rome (1931), Harvard Journal of Asiatic Studies (1936), Harvard Studies in Classical Philology (1890), Hesperia (1932), Hispanic American Historical Review (1918), Hispanic Review (1933), Historical Journal (1958), History and Theory (1960), History of Education Quarterly (1961), 
History Teacher (1967), Incorporated Statistician (1950), Industrial and Labor Relations Review (1947), International Affairs (1931), International Economic Review (1960), International Family Planning Digest (1975), International Family Planning Perspectives (1979), International Family Planning Perspectives and Digest (1978), International Journal of Ethics (1890), International Migration Digest (1964), International Migration Review (1966), International Organization (1947), International Studies Quarterly (1967), Isis (1913), Italica (1926), Journal of Accounting Research (1963), Journal of Aesthetics and Art Criticism (1941), Journal of African History (1960), Journal of American Folklore (1888), Journal of American History (1914), Journal of Animal Ecology (1932), Journal of Applied Ecology (1964), Journal of Applied Econometrics (1986), Journal of Asian Studies (1956), Journal of Black Studies (1970), Journal of British Studies (1961), Journal of Business (1954), Journal of Business of the University of Chicago (1928), Journal of Conflict Resolution (1957), Journal of Contemporary History (1966), Journal of Ecology (1913), Journal of Economic Abstracts (1963), Journal of Economic History (1941), Journal of Economic Literature (1969), Journal of Economic Perspectives (1987), Journal of Educational Sociology (1927), Journal of Finance (1946), Journal of Financial and Quantitative Analysis (1966), Journal of Health and Human Behavior (1960), Journal of Health and Social Behavior (1967), Journal of Hellenic Studies (1880), Journal of Higher Education (1930), Journal of Human Resources (1966), Journal of Industrial Economics (1952), Journal of Inter-American Studies (1959), Journal of Latin American Studies (1969), Journal of Marriage and the Family (1964), Journal of Military History (1989), Journal of Modern African Studies (1963), Journal of Modern History (1929), Journal of Money, Credit and Banking (1969), Journal of Near Eastern Studies (1942), Journal of Negro Education (1932), Journal of Negro History (1916), Journal of Peace Research (1964), Journal of 
Philosophy (1921), Journal of Philosophy, Psychology and Scientific Methods (1904), Journal of Political Economy (1892), Journal of Politics (1939), Journal of Risk and Insurance (1964), Journal of Roman Studies (1911), Journal of Social Forces (1922), Journal of Southern History (1935), Journal of Symbolic Logic (1936), Journal of the Academy of Management (1958), Journal of the American Association of University Teachers of Insurance (1937), Journal of the American Geographical Society (1859), Journal of the American Mathematical Society (1988), Journal of the American Military History Foundation (1937), Journal of the American Military Institute (1939), Journal of the American Oriental Society (1854), Journal of the American Statistical Association (1922), Journal of the Anthropological Institute of Great Britain and Ireland (1872), Journal of the British Institute of International Affairs (1922), Journal of the History of Idea (1940), Journal of the Royal Anthropological Institute of Great Britain and Ireland (1871), Journal of the Royal Geographical Society of London (1831), Journal of the Royal Institute of International Affairs (1926), Journal of the Royal Statistical Society (1887), Journal of the Society for Industrial and Applied Mathematics (1953), Journal of the Statistical Society of London (1838), Journal-Newsletter of the Association of Teachers of Japanese (1963), Language (1925), Latin American Research Review (1965), Limnology and Oceanography (1956), Man (1901), Management Science (1954), Management Technology (1960), Marriage and Family Living (1941), Mathematical Tables and Other Aids to Computation, Mathematics Magazine (1947), Mathematics Newsletter (1926), Mathematics of Computation (1960), Memorandum of Institute of Pacific Relations (1932), Midwest Journal of Political Science (1957), Military Affairs (1941), Mind (1876), Mississippi Valley Historical Review (1914), Missouri Botanical Garden Annual Report (1890), Modern Asian Studies (1967), Modern Language Journal (1916), Modern Language Notes (1886), Modern Philology (1903), 
Monumenta Nipponica (1938), National Mathematics Magazine (1934), Negro American Literature Forum (1967), New England Quarterly (1928), New Literary History (1969), New Phytologist (1902), News Bulletin (Institute of Pacific Relations) (1926), Nineteenth-Century Fiction (1949), Nineteenth-Century Literature (1986), Notes and Records of the Royal Society of London (1938), Noûs (1967), Operations Research (1956), OR (1950), Osiris (1936), Oxford Economic Papers (1938), Pacific Affairs (1928), Past and Present (1952), Philosophical Perspectives (1987), Philosophical Quarterly (1950), Philosophical Review (1892), Philosophical Transactions of the Royal Society of London (1776), Philosophy and Phenomenological Research (1940), Philosophy and Public Affairs (1971), Philosophy of Science (1934), Phylon (1960), Political Science Quarterly (1886), Population and Development Review (1975), Population Index (1937), Population Literature (1935), Population Studies (1947), Population: An English Selection (1989), Proceedings of the American Mathematical Society (1950), Proceedings of the American Political Science Association (1904), Proceedings of the Modern Language Association of America (1886), Proceedings of the National Academy of Sciences of the United States of America (1915), Proceedings of the Royal Anthropological Institute of Great Britain and Ireland (1965), Proceedings of the Royal Anthropological Institute of Great Britain and Ireland (1965), Proceedings of the Royal Geographical Society (1857), Proceedings of the Royal Society of London (1854), Public Opinion Quarterly (1937), Publications of the American Economic Association (1886), Publications of the American Statistical Association (1888), Quarterly Journal of Economics (1886), Quarterly Publications of the American Statistical Association (1920), Quarterly Review of Biology (1926), RAIN (1974), Renaissance News (1948), Renaissance Quarterly (1967), Representations (1983), Review of Economic Studies (1933), Review of Economics and Statistics (1919), Review of English Studies 
(1925), Review of Financial Studies (1988), Reviews in American History (1973), Russian Review (1941), Science (1880), Scientific Monthly (1915), Shakespeare Quarterly (1950), SIAM Journal on Applied Mathematics (1966), SIAM Journal on Numerical Analysis (1966), SIAM Review (1959), Slavic and East European Journal (1957), Slavic Review (1961), Social Forces (1925), Social Psychology (1978), Social Psychology Quarterly (1979), Sociological Methodology (1969), Sociology of Education (1963), Sociometry (1937), Soviet Studies (1949), Speculum (1926), Statistical Science (1986), Statistician (1962), Studies in English Literature (1961), Studies in Family Planning (1963), Studies in the Renaissance (1954), Systematic Zoology (1952), Transactions and Papers (Institute of British Geographers) (1935), Transactions and Proceedings of the American Philological Association (1869), Transactions of the American mathematical Society (1900), Transactions of the Anthropological Society of Washington (1885), Transition (1961), Trollopian (1945), Twentieth Century Literature (1955), University Journal of Business (1922), Western Political Quarterly (1948), William and Mary Quarterly (1892), World Archaeology (1969), World Politics (1948), Yale French Studies (1948), Yearbook of Anthropology (1955). 


\section{Notes}

${ }^{1}$ The author is very grateful to Howard Aldrich, Robert Bannister, Marion Blute, Gregory Claeys, Denise Dollimore, Gerald Gaus, David Hull, Matthias Klaes, Thorbjørn Knudsen, John Laurent, Peter Richerson, Jack Vromen, John van Wyhe, anonymous referees and others for valuable help and extensive comments.

${ }^{2}$ A strong argument in favor of investigations into the history of the use of key terms in discourse, alongside the history of the ideas that such terms may represent, is made in Klaes (2001).

${ }^{3}$ Racist, sexist, individualist and imperialist notions were evident in other pre-1945 scientific literatures, including in Continental Europe. Darwin’s ideas were also influential in Europe. But the connection between the two sets of ideas in the Continental literature is under dispute (McGovern, 1941; Gasman, 1971, 1998; Kelly, 1981; Benton, 1982; Bellomy, 1984; L. Clark, 1985; Weikart, 1993, 2002). No presumption is made here whether or not the conclusions that apply to Anglophone journals apply to other academic literatures as well. There is clearly a need for citation-based studies of these other literatures.

${ }^{4}$ JSTOR user services can be contacted via jstor-info@umich.edu or jstor@mimas.ac.uk. The list of journals searched is in the Appendix. Hereafter in the text, any reported search for the term 'Social Darwinism' also involved the simultaneous search for the alternative terms 'Social 
Darwinist' or 'Social Darwinists'. With the kind assistance of R. Bannister, additional electronic journal databases at Cornell University (http://cdl.library.cornell.edu/moa/) and at the University of Michigan (http://moa.umdl.umich.edu/) were also searched. The journals on these databases are not entirely academic in nature, and most of the material is from the nineteenth century. The term 'Social Darwinism' was not found in these additional databases, although by the 1880s there were several references to Darwin and Darwinism.

${ }^{5}$ The frequency claims made here are strictly limited to the journal literature. However, I know of no book in English of academic importance or impact in the 1890-1950 period in the social sciences that was not itself reviewed in a journal in the JSTOR database. If 'Social Darwinism' were a term used extensively in the book in question, then it would be likely to be mentioned in the journal review. Hence, the exclusive use of academic journals is not an excessive limitation here. However, a citation study of academic monographs is a project for another essay.

${ }^{6}$ These past applications of core Darwinian theory to social evolution are discussed in more detail in Hodgson (2004).

${ }^{7}$ An exception is Coats (1954, p. 532) who saw Veblen as adopting 'an extreme form of Social Darwinism'. See also Keller (1915, pp. 10-11) and note 16 below. Another exception is Hawkins (1997) who criticizes Ritchie as a 'reform Darwinist' but ignores Veblen. It is not clear why Bagehot, Drummond, Ritchie or Veblen have not been referred to more widely as 'Social Darwinists', other than the term before 1940 was extremely rare, and after 1940 it was more prominently associated with competitive individualists or racists. The idea that the core 
Darwinian theoretical principles might be applied to social evolution was discussed less frequently after the First World War, and until recently has remained a relatively neglected and misunderstood theme (Hodgson, 2002, 2004).

${ }^{8}$ However, despite Kropotkin's erudite use of Darwinian views in social science, his political ideas were so remote from twentieth-century caricatures of 'Social Darwinism' that Hawkins (1997, pp. 178-80) attempted unconvincingly to exclude Kropotkin from his broad definition of 'Social Darwinism', which includes anyone who believed that principles of evolution in nature have something to do with human society. See Johnson (1998) for a critical review of Hawkins's book.

${ }^{9}$ This is not to deny some of the ramifications of Darwin's wider views, explored by Desmond and Moore (1991) and Young (1985).

${ }^{10}$ Claeys (2000, p. 228) argues that 'the concept of "Social Darwinism," insofar as it focuses centrally on the idea of the "survival of the fittest," is to a significant degree a misnomer. Much of what we associate with the concept had been in formation for over half a century by the time the Origin of Species appeared in 1859.'

${ }^{11}$ An exception was Wells (1907), as noted below. Liberals and socialists such as E. Aveling, E. Bellamy, C. H. Cooley, J. B. S. Haldane, J. Huxley, J. M. Keynes, H. J. Laski, J. Needham, G. B. Shaw, C. P. Snow, B. Webb, S. Webb and H. G. Wells counted themselves as followers of eugenics (Paul, 1984). Critics included F. Boas, B. Kidd and L. Ward. 
12 However, some early Continental critics of what they described as 'Social Darwinism' after 1880 did associate this term with individualistic competition, and also criticized Spencer in this vein (L. Clark, 1985). But as shown below there is no evidence in the pre-1937 Anglophone journals searched here of any direct association of Spencer with the 'Social Darwinism' label.

${ }^{13}$ If the JSTOR search is extended to minor items other than articles and reviews, then there are a few further appearances of 'Social Darwinism'. The very first citation, in Mind in 1887, notes the appearance of the term as a chapter heading (in Italian) in De Sarlo (1887). De Sarlo defended Darwinism, but because of the possible triumph of human intelligence over struggle, he did not believe that it applied to social evolution. He thus rejected 'Social Darwinism' as misconceived. Also the Economic Journal in 1895 notes the publication of Loria (1895), discussed below. An 1896 article in French by Loria was abstracted in the American Journal of Sociology in 1897. A further JSTOR article of 1911 alludes in a footnote to Novicow's (1910) La critique du darwinisme social, without using the English term. Because these minor mentions are in neither articles nor reviews, they are not included in the bibliometric data presented here.

${ }^{14}$ This number drops to 887 if the phrase 'Herbert Spencer' is required in the citation. Given that there were several writers named Spencer, the number of citations to Herbert Spencer is likely to be greater than 887 but less than 2,786.

${ }^{15}$ Ironically, Ward himself has subsequently been lumped within Social Darwinism (Hofstadter, 1944). But Ward (1907a, 1907b) repeatedly attacked the abuse of biology for ideological causes and argued that the outcome of evolution, whether in nature or society, was rarely if ever optimal. 
He promoted women's rights and opposed racism. Ward (1913) referred disapprovingly to 'Social Darwinism', where he again criticized eugenics and drew attention to his 1907 remarks against Wells.

${ }^{16}$ Interestingly, when Sumner's student Keller (1915, pp. 10-11) mentioned once in a book the term 'Social Darwinism' he referred to some alleged proponents, but not in that context to Sumner. Furthermore, Keller's definition of 'Social Darwinism' was not as a political or ideological creed but in terms of attempts to 'extend Darwinian evolution into the field of the social sciences'. Keller named 'Ritchie, Kidd, and especially Bagehot' as pioneers of the application of Darwinian theoretical principles to the social sciences. Keller's book is exceptional for this period, both for a rare appearance of the 'Social Darwinism' term, and for his own attempt to apply Darwinian theoretical principles to social evolution, without explanatory reduction to biology. See the discussion of Keller in Campbell (1964).

${ }^{17}$ Veblen $(1899,1919)$ was one of the few people (alongside Bagehot, Ritchie and Keller) to apply Darwinism theoretical principles to social evolution. As a student, Parsons read Veblen's writings, but in the 1930s he made a deliberate break from his own Veblenian past (Camic, 1987, 1991; Hodgson, 2001). It is possible that Parsons was alluding to Veblen in this footnote of 1932.

${ }^{18}$ The first Anglophone suggestion that Sumner was a Social Darwinist that I have come across is by Stern (1933). Ellwood (1938, p. 505) argued that Sumner was 'much closer to the social Darwinists’ than Spencer, thus excluding the latter from this category. 
${ }^{19}$ By contrast, the writings of Ammon and Lapouge were preoccupied with explanations of social phenomena in terms of alleged racial characteristics. Lapouge’s studies of 'Aryanism' were fêted by the Nazis.

${ }^{20}$ Hofstadter (1941) was one of the first to propose in English that Sumner was a 'Social Darwinist'.

${ }^{21}$ Ironically, Parsons $(1966,1977)$ later made some use of biological analogies in his work.

22 Although the proposition here that Spencer and Sumner were not described as Social Darwinists before the 1930s is strictly confined to the JSTOR journals, the present author has not discovered any earlier description of them as Social Darwinist in any English publication. Evidence to the contrary would be welcomed.

${ }^{23}$ It is not the purpose of this essay to scrutinize the scientific content of sociobiology. Elsewhere sociobiology has been criticized for its over-extended attempts to reduce social phenomena to biological terms (Sahlins, 1977; Boyd and Richerson, 1980; Rose et al., 1984; Durham, 1991; Hodgson, 1993).

${ }^{24}$ Veblen could likewise be prosecuted for his excessive use of the concept of instinct, and Marshall for his invocation of flawed Spencerian biology (Hodgson, 1993, 2004).

${ }^{25}$ Bannister's excellent book received some attention, and 17 citations in JSTOR books and articles in the 1980s.

\section{References}


Allen, E. et al. (35 authors comprising the Sociobiology Study Group of Science for the People) (1976) ‘Sociobiology - Another Biological Determinism’, Bioscience, 26(3), pp. 182-6.

Bagehot, Walter (1872) Physics and Politics, or, Thoughts on the Application of the Principles of 'Natural Selection' and 'Inheritance’ to Political Society (London: Henry King).

Bain, Read (1932) Review of Thorstein Veblen and His America by Joseph Dorfman and What Veblen Taught edited by Wesley Mitchell, American Sociological Review, 1(3), June, pp. 48587.

Bain, Read (1940) Review of The Individual and Its Society by Abram Kardiner and Ralph Linton, American Sociological Review, 5(2), April, pp. 254-7.

Bannister, Robert C. (1973) ‘William Graham Sumner’s Social Darwinism: A Reconsideration’, History of Political Economy, 5(1), Spring, pp. 89-108.

Bannister, Robert C. (1979) Social Darwinism; Science and Myth in Anglo-American Social Thought (Philadelphia: Temple University Press).

Barnes, Harry Elmer (1921) 'Some Contributions of Sociology to Modern Political Theory', American Political Science Review, 15(4), November, pp. 487-533.

Barnes, Harry Elmer (1932) 'The Development of Sociology', Scientific Monthly, 35(6), December, pp. 543-53.

Bellomy, Donald C. (1984) “'Social Darwinism” Revisited', Perspectives in American History, New Series, 1, pp. 1-129. 
Benton, Ted (1982) 'Social Darwinism and Socialist Darwinism in Germany: 1860-1900', Revista di filosofia, 73, pp. 79-121.

Bowler, Peter J. (1983) The Eclipse of Darwinism: Anti-Darwinian Evolution Theories in the Decades around 1900 (Baltimore: Johns Hopkins University Press).

Bowler, Peter J. (1988) The Non-Darwinian Revolution: Reinterpreting a Historical Myth (Baltimore: Johns Hopkins University Press).

Boyd, Robert and Richerson, Peter J. (1980) 'Sociobiology, Culture and Economic Theory', Journal of Economic Behavior and Organization, 1(1), March, pp. 97-121.

Camic, Charles (1987) 'The Making of a Method: A Historical Reinterpretation of the Early Parsons’, American Sociological Review, 52(4), August, pp. 421-39.

Camic, Charles (ed.) (1991) Talcott Parsons: The Early Essays (Chicago: University of Chicago Press).

Campbell, Donald T. (1965) 'Variation, Selection and Retention in Sociocultural Evolution', in Barringer, H. R., Blanksten, G. I. and Mack, R. W. (eds) (1965) Social Change in Developing Areas: A Reinterpretation of Evolutionary Theory (Cambridge, MA: Schenkman), pp. 19-49. Reprinted in General Systems, 14, 1969, pp. 69-85.

Case, Clarence Marsh (1922) 'Instinctive and Cultural Factors in Group Conflicts', American Journal of Sociology, 28(1), July, pp. 1-20.

Claeys, Gregory (2000) 'The "Survival of the Fittest" and the Origins of Social Darwinism, Journal of the History of Ideas, 61(2), pp. 223-40. 
Clark, Evalyn A. (1940) 'Adolph Wagner: From National Economist to National Socialist', Political Science Quarterly, 55(3), September, pp. 378-411.

Clark, Linda L. (1985) Social Darwinism in France (Tuscaloosa: University of Alabama Press).

Coats, A. W. (1954) 'The Influence of Veblen’s Methodology', Journal of Political Economy, 62(6), December, pp. 529-37.

Cravens, Hamilton (1978) The Triumph of Evolution: American Scientists and the HereditaryEnvironment Controversy, 1900-1941 (Philadelphia: University of Pennsylvania Press).

Crook, Paul (1994) Darwinism, War and History: The Debate over the Biology of War from the 'Origin of Species' to the First World War (Cambridge: Cambridge University Press).

De Sarlo, Francesco (1887) Studi sul Darwinismo (Napoli: Tocco).

Degler, Carl N. (1991) In Search of Human Nature: The Decline and Revival of Darwinism in American Social Thought (Oxford and New York: Oxford University Press).

Desmond, Adrian and Moore, James R. (1991) Darwin (London: Michael Joseph).

Dorfman, Joseph (1934) Thorstein Veblen and His America (New York: Viking Press). Reprinted 1961 (New York: Augustus Kelley).

Drummond, Henry (1894) The Ascent of Man (London: Hodder and Stoughton).

Durham, William H. (1991) Coevolution: Genes, Culture, and Human Diversity (Stanford: Stanford University Press).

Ellwood, Charles A. (1938) A History of Social Philosophy (New York: Prentice-Hall). 
Gasman, Daniel (1971) The Scientific Origins of National Socialism: Social Darwinism in Ernst Haeckel and the German Monist League (London: Macdonald).

Gasman, Daniel (1998) Haeckel's Monism and the Birth of Fascist Ideology (New York: Lang).

Gittler, Joseph B. (1942) 'Schema for Studying the Social Effects of Inventions', Sociometry, 5(4), November, pp. 382-94.

Grant, John E. (1922) The Problem of War and Its Solution (New York: Dutton).

Haeckel, Ernst (1874) Anthropogenie oder Entwicklungsgeschichte des Menschen (Leipzig: Engelmann).

Hawkins, Mike (1997) Social Darwinism in European and American Thought, 1860-1945: Nature as Model and Nature as Threat (Cambridge: Cambridge University Press).

Himmelfarb, Gertrude (1959) Darwin and the Darwinian Revolution (London: Chatto and Windus).

Hodgson, Geoffrey M. (1993) Economics and Evolution: Bringing Life Back Into Economics (Cambridge, UK and Ann Arbor, MI: Polity Press and University of Michigan Press).

Hodgson, Geoffrey M. (1999) Evolution and Institutions: On Evolutionary Economics and the Evolution of Economics (Cheltenham: Edward Elgar).

Hodgson, Geoffrey M. (2001) How Economics Forgot History: The Problem of Historical Specificity in Social Science (London and New York: Routledge).

Hodgson, Geoffrey M. (2002) 'Darwinism in Economics: From Analogy to Ontology', Journal of Evolutionary Economics, 12(2), June, pp. 259-81. 
Hodgson, Geoffrey M. (2004) The Evolution of Institutional Economics: Agency and Structure in American Institutionalism (London and New York: Routledge).

Hofstadter, Richard (1941) 'William Graham Sumner, Social Darwinist', New England Quarterly, 14, pp. 457-77.

Hofstadter, Richard (1944) Social Darwinism in American Thought, 1860-1915, 1st edn. (Philadelphia: University of Pennsylvania Press).

Holmes, S. J. (1919) 'Social Amelioration and Eugenic Progress', Scientific Monthly, 8(1), January, pp. 16-31.

Holmes, S. J. (1932) ‘The Changing Effects of Race Competition’, Science, 75, February 19, pp. 201-8.

Johnson, Gary R. (1998) Review of Social Darwinism in European and American Thought, 1860-1945: Nature as Model and Nature as Threat by Mike Hawkins, American Political Science Review, 92(4), December, pp. 930-2.

Jones, Greta (1980) Social Darwinism and English Thought (Brighton, UK and Atlantic Highlands, NJ: Harvester and Humanities Press).

Keller, Albert Galloway (1915) Societal Evolution: A Study of the Evolutionary Basis of the Science of Society (New York: Macmillan).

Keller, Albert Galloway (1923) 'Societal Evolution’, in Baitsell, George Alfred (ed.) (1923) The Evolution of Man (New Haven: Yale University Press), pp. 126-51. 
Keller, Albert Galloway (1945) Review of Social Darwinism in American Thought, 1860-1915 by Richard Hofstadter, Scientific Monthly, 60(5), May, pp. 398-9.

Kelly, Alfred (1981) The Descent of Darwin: The Popularization of Darwinism in Germany, 1860-1914 (Chapel Hill, NC: University of North Carolina Press).

Klaes, Matthias (2001) 'Begriffsgeschichte: Between the Scylla of Conceptual and the Charybdis of Institutional History of Economics', Journal of the History of Economic Thought, 23(2), pp. 153-79.

Kropotkin, Petr A. (1902) Mutual Aid: A Factor of Evolution, 1st edn. (London: Heinemann).

Laurent, John (2000) 'Alfred Marshall's Annotations on Herbert Spencer's Principles of Biology', Marshall Studies Bulletin, 7, pp. 1-6.

Le Conte, Joseph (1892) The Race Problem in the South (New York: Appleton).

Loria, Achille (1895) Problemi Sociali Contemporanei (Milano: Kantorowicz).

Marshall, Alfred (1890) Principles of Economics: An Introductory Volume, 1st edn. (London: Macmillan).

McGovern, William M. (1941) From Luther to Hitler: The History of Fascist-Nazi Political Philosophy (Boston: Houghton Mifflin).

Mitchell, Wesley C. (ed.) (1936) What Veblen Taught (New York: Viking).

Mumford, Lewis (1944) The Condition of Man (New York: Harcourt, Brace). 
Nasmyth, George (1916) Social Progress and Darwinian Theory: A Study of Force as a Factor in Human Relations (New York and London: Putnam).

Novicow, Jacques (1910) La critique du darwinisme social (Paris: Alcan).

Parsons, Talcott (1932) 'Economics and Sociology: Marshall in Relation to the Thought of his Time’, Quarterly Journal of Economics, 46(2), February, pp. 316-47.

Parsons, Talcott (1934) 'Some Reflections on "The Nature and Significance of Economics”', Quarterly Journal of Economics, 48(3), May, pp. 511-45.

Parsons, Talcott (1937) The Structure of Social Action, 2 vols (New York: McGraw-Hill).

Parsons, Talcott (1966) Societies: Evolutionary and Comparative Perspectives (Engelewood Cliffs, NJ: Prentice-Hall).

Parsons, Talcott (1977) The Evolution of Societies (Engelewood Cliffs, NJ: Prentice-Hall).

Paul, Diane (1984) 'Eugenics and the Left', Journal of the History of Ideas, 45(4), OctoberDecember, pp. 567-590

Perry, Ralph Burton (1918) The Present Conflict of Ideals: A Study of the Philosophical Background of the World War (New York: Longmans Green).

Pittenger, Mark (1993) American Socialists and Evolutionary Thought, 1870-1920 (Madison, WS: University of Wisconsin Press).

Richerson, Peter J. and Boyd, Robert (2001) 'Built For Speed, Not for Comfort: Darwinian Theory and Human Culture', History and Philosophy of the Life Sciences, 23, pp. 423-63. 
Ritchie, David G. (1896) ‘Social Evolution’, International Journal of Ethics, 6(2), pp. 165-81.

Rogin, Leo (1937) Review of Bourgeois Population Theory: A Marxist-Leninist Critique, American Economic Review, 27(2), June, pp. 412-14.

Rose, Steven, Kamin, Leon J. and Lewontin, Richard C. (1984) Not in Our Genes: Biology, Ideology and Human Nature (Harmondsworth: Penguin).

Ross, Edward Alsworth (1903) 'Recent Tendencies in Sociology III', Quarterly Journal of Economics, 17(3), May, pp. 438-55.

Sahlins, Marshall D. (1977) The Use and Abuse of Biology: An Anthropological Critique of Sociobiology (London: Tavistock).

Schmidt, Oskar (1879) ‘Science and Socialism’, Popular Science, 14, pp. 557-91.

Segerstrale, Ullica (2000) Defenders of the Truth: The Sociobiology Debate (Oxford: Ooxford University Press).

Shute, Daniel K. (1896) ‘Racial Anatomical Peculiarities’, American Anthropologist, 9, April, pp. $123-7$.

Smith, Norman E. (1979) 'William Graham Sumner as an Anti-Social Darwinist', Pacific Sociological Review, 22, pp. 332-47.

Spencer, Herbert (1893) 'The Inadequacy of Natural Selection', Contemporary Review, 63, pp. 153-66, 439-56.

Stapleton, Laurence (1944) Justice and World Society (Chapel Hill: University of North Carolina Press). 
Stern, Bernhard J. (1933) 'Sumner, William Graham', in Edwin R. A. Seligman and Alvin Johnson (eds) Encyclopaedia of the Social Sciences (New York: Macmillan), Vol. 9, p. 463.

Sumner, William Graham (1906) Folkways: A Study of the Sociological Importance of Usages, Manners, Customs, Mores and Morals (Boston: Ginn).

Tarde, Gabriel (1884) 'Darwinisme naturel et Darwinisme social', Revue Philosophique, 17, p. 607.

Tarde, Gabriel (1890) Les lois de l’imitation: étude sociologique (Paris: Alcan).

Taussig, Frank W. (1895) Review of Achille Loria Problemi Sociali Contemporani, Political Science Quarterly, 10(3), September, pp. 537-8.

Thomas, Brinley (1991) 'Alfred Marshall on Economic Biology’, Review of Political Economy, 3(1), January, pp. 1-14.

Veblen, Thorstein B. (1899) The Theory of the Leisure Class: An Economic Study in the Evolution of Institutions (New York: Macmillan).

Ward, Lester Frank (1907a) ‘Discussion’ of Wells (1907), American Journal of Sociology, 12(5), March, pp. 709-10.

Ward, Lester Frank (1907b) 'Social and Biological Struggles', American Journal of Sociology, 13(3), November, pp. 289-99.

Ward, Lester F. (1913) 'Eugenics, Euthenics, and Eudemics’, American Journal of Sociology, 18(6), May, pp. 737-54. 
Waters, C. Kenneth (1986) 'Natural Selection Without Survival of the Fittest', Biology and Philosophy, 1(2), April, pp. 207-25.

Weikart, Richard (1993) 'The Origins of Social Darwinism in Germany, 1859-1895', Journal of the History of Ideas, 54(3), July, pp. 469-88.

Weikart, Richard (2002) 'Darwinism and Death: Devaluing Human Life in Germany 1859-1920’, Journal of the History of Ideas, 63(2), July, pp. 323-44.

Weingart, Peter, Mitchell, Sandra D, Richerson, Peter J. and Maasen, Sabine (eds) (1997) Human By Nature: Between Biology and the Social Sciences (Mahwah, NJ: Lawrence Erlbaum Associates).

Wells, D. Collin (1907) 'Social Darwinism’, American Journal of Sociology, 12(5), March, pp. 695-708.

Wilson, Edward O. (1975) Sociobiology: The New Synthesis (Cambridge, MA: Harvard University Press).

Wilson, Edward O. (1978) On Human Nature (Cambridge, MA: Harvard University Press).

Wiltshire, David (1978) The Social and Political Thought of Herbert Spencer (Oxford: Oxford University Press).

Woods, Erville B. (1920) 'Heredity and Opportunity', American Journal of Sociology, 26(1), July, pp. 1-21.

Wuarin, Louis (1896) Une vue d'ensemble de la question sociale: le problème, la méthode (Paris: Larose). 
Young, Robert M. (1985) Darwin’s Metaphor: Nature’s Place in Victorian Culture (Cambridge: Cambridge University Press).

Zilboorg, Gregory (1921) 'Reflections on a Century of Political Experience and Thought', Political Science Quarterly, 36(3), September, pp. 391-408. 